8. Fitzpatrick R, Davey C, Buxton MJ, Jones DR. Evaluating patient-based outcome measures for use in clinical trials. Health Technology Assessment 1998;2(14):1-74.

9. Pinnock H, Sheikh A, Juniper E. Evaluation of an intervention to improve successful completion of the Mini-AQLQ: comparison of postal and supervised completion. Prim Care Respir J 2004;13:36-41. http://dx.doi.org/10.1016/j.pcrj.2003.11.004

10. Pinnock $H$, Sheikh $A$, Juniper $E$. Concordance between supervised and postal administration of the MiniAQLQ and ACQ is very high. J Clin Epidemiol 2005;58:809-14. http://dx.doi.org/10.1016/j.jclinepi.2005.01.010

11. Juniper EF, Bousquet J, Abetz L, Bateman ED. Identifying 'well-controlled' and 'not well-controlled' asthma using the Asthma Control Questionnaire. Respir Med 2006;100:616-21. http://dx.doi.org/10.1016/j.rmed.2005.08.012

12. Mitchell C, Dwyer R, Hagan T, Mathers N. Impact of the QOF and the NICE guideline in the diagnosis and management of depression: a qualitative study. $\mathrm{Br}$ J Gen Pract 2011;61:343-4. http://dx.doi.org/10.3399/bjgp11X572472

13. Glasgow NJ, Ponsonby A-L, Yates R, Beilby J, Dugdale P. Proactive asthma care in childhood: general practice based randomised controlled trial. BMJ 2003;327:65965. http://dx.doi.org/10.1136/bmj.327.7416.659

14. Ventres W, Kooienga S, Vuckovic N, Marlin R, Nygren P, Stewart V. Physicians, Patients, and the Electronic Health Record: An Ethnographic Analysis. Ann Fam Med 2006;4:124-1. http://dx.doi.org/10.1370/afm.425
15. Rhodes P, Langdon M, Rowley E, Wright J, Small N. What Does the Use of a Computerized Checklist Mean for Patient-Centered Care? The Example of a Routine Diabetes Review. Qualitative Health Research 2006;16:353-76. http://dx.doi.org/10.1177/1049732305282396

16. Brownbridge G, Evans A, Fitter M, Platts M. An interactive computerized protocol for the management of hypertension: effects on the general practitioner's clinical behaviour. J Royal Coll Gen Practitioners 1986;36:198-202.

17. Haahtela T, Klaukka T, Koskela K, et al. Asthma programme in Finland: a community problem needs community solutions. Thorax 2001;56:806-14. http://dx.doi.org/10.1136/thorax.56.10.806

18. Vollmer WM, Markson LE, O'Connor E, Frazier EA, Berger M, Buist AS. Association of Asthma Control with Health Care Utilization: A Prospective Evaluation. Am J Respir Crit Care Med 2002;165:195-9.

19. Sims EJ, for the HARP study group. Helping Asthma in Real Patients (The HARP study): Interim Report for the IPCRG. Available from http://www.theipcrg.org/resneeds/harp.php (accessed January 2012)

20. Department of Health. Equity and Excellence: Liberating the NHS. London: Department of Health, 2010 (Cm 7881)

21. The Information Centre. Quality and Outcomes Framework Achievement Data 2010/11. Available from http://www.ic.nhs.uk (accessed 8.1.12)

\title{
Perceptions of risk may explain the discrepancy between patient and clinician-recorded symptoms
}

\section{See linked article by Barbara et al. on pg 145}

\section{Ian Dawson ${ }^{\mathrm{a}}$, Victoria Senior ${ }^{\mathrm{b}}$ *Simon de Lusignanc}

a Lecturer in Human Resource Management \& Organisational Behaviour, The Surrey Business School, University of Surrey, UK

b Senior Lecturer in Health Psychology, School of Psychology, University of Surrey, UK

c Professor of Primary Care and Clinical Informatics, Department of Health Care Management and Policy, University of Surrey, UK

*Correspondence:

Professor Simon de Lusignan, Professor of Primary Care and Clinical Informatics, Department of Health Care Management and Policy, University of Surrey, Guildford, GU2 7PX, UK Tel: +44(0)1483 683089 Fax: +44(0)1483 686208 E-mail: s.lusignan@surrey.ac.uk

In this issue of the PCRJ, Barbara and colleagues ${ }^{1}$ report the agreement between patient-recorded and clinician-recorded symptoms of respiratory illness. Contrary to other research, the study revealed that the patients recorded fewer symptoms than were captured by the clinicians following consultation. Barbara et al.'s intriguing findings raise two key questions. First, what factors might cause patients to increase the quantity of the symptoms that they report when conversing with their clinician? Second, are there any reasons why clinicians may record symptoms in addition to the symptoms presented by the patients during consultation? We believe the answer to these questions may be explained by considering the psychological factors that may underlie patient and clinician symptom-recording behaviours. More specifically, we suggest that the different symptom-recording behaviours of patients and clinicians may be motivated by an intrinsic desire to manage perceived risks.

When patients visit their physician they often arrive with an agenda and expectation of receiving a prescription, particularly when they believe they have a respiratory illness. ${ }^{2,3}$ Such expectations seem reasonable given that patients typically visit their clinicians to obtain a solution (e.g. a prescription) to a problem (e.g. a respiratory infection). However, patients may perceive a risk that the clinician will not provide the anticipated solution and therefore not address the problem to a satisfactory standard. This perceived risk may be heightened as a result of the rise in public awareness of current campaigns to discourage clinicians from prescribing certain medications (e.g. antibiotics) due to costs, misuse and a slow decline in effectiveness (see Figure 1).,5 Consequently, patients may now perceive the risk of leaving the practice without an appropriate remedy as being much greater than in previous decades. In an attempt to manage this risk, we hypothesise that patients may report a greater quantity of symptoms during clinical consultations, with the intention of encouraging the clinician to diagnose an illness that would typically warrant a prescription. In short, the 'over-reporting' of symptoms by patients may lead some clinicians to record a greater quantity of symptoms than those recorded by the patient prior to the consultation. This thesis provides a potential explanation for Barbara et al.'s main finding that patients and clinicians record a different quantity of symptoms and for the contrast between this finding and findings observed in earlier work.

This notion is further supported by Barbara et al.'s finding that the symptoms which patients under-recorded (e.g. cough, fever, etc.) appear to be those that may be more difficult for a clinician to verify objectively in a short consultation. This behaviour may stem from the 
Figure 1. Canadian antibiotic awareness campaign (http://antibioticawareness.ca/)
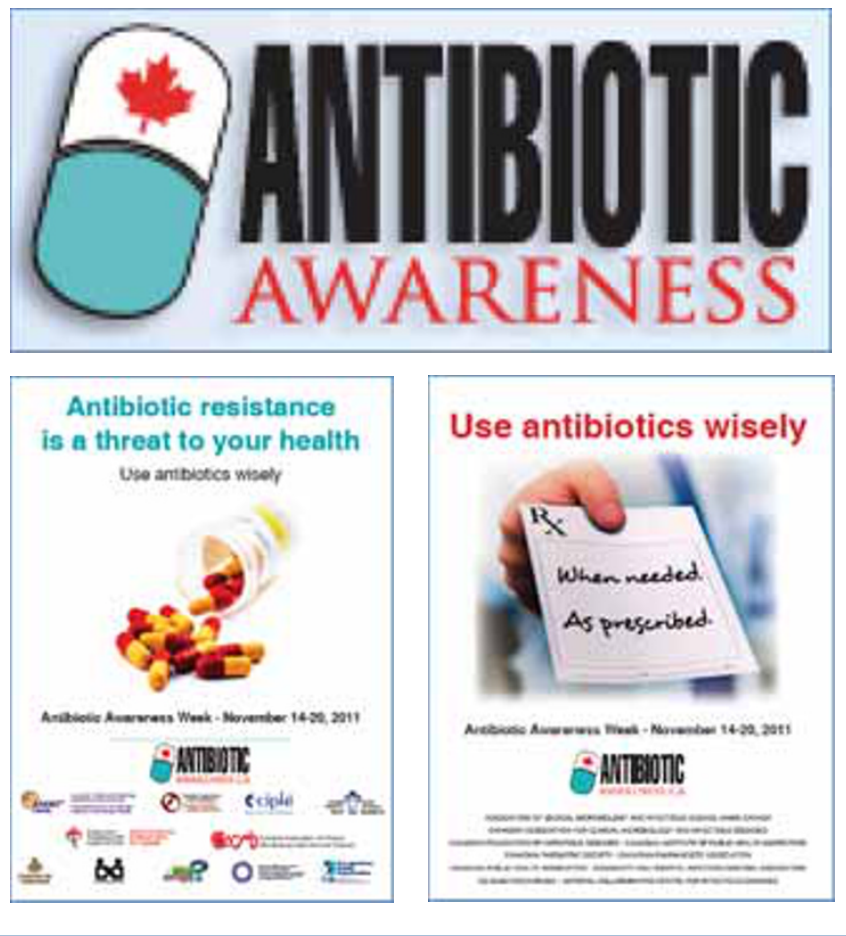

patient's perceived risk of not receiving help for an illness due to policy agendas enacted within the health system.

The discrepancies between patient-recorded and clinicianrecorded symptoms could be attributable to the behavioural risk management strategies employed, either knowingly or unknowingly, by clinicians. Research shows that clinicians often recognise that patients expect to receive prescription medication as a result of a consultation and that clinicians worry that a failure to meet such expectations may damage the clinician-patient relationship. ${ }^{6,7}$ To ameliorate the perceived risk of failing to meet patients' expectations the clinician may, following an examination and diagnosis, issue a prescription or alternative form of clinical intervention (e.g. referral). To ensure these actions are defendable, the clinician then records a list of symptoms that are typical of the diagnosed condition - a list that may extend beyond the symptoms reported by the patient. Sometimes practitioners are aware that they are using a diagnostic label to justify their decision to treat:

" .... when someone comes along in the flu season, and they've got a viral type infection, and it may be viral... ... There's a bit of you that says this is probably viral, so I ought to really code it as virus infection, don't know what virus but that doesn't matter, but because they've got a yellow coloured sputum, you say oh well, that sounds like a bacterial thing and I'm giving them antibiotics, so I'll call it bronchitis. So I actually put down acute bronchitis. So yes, in a sense, you are altering diagnoses... .... it is playing a kind of a game in a sense for the doctor to justify what he has done, depending upon the decision he came up with." ${ }^{8}$
Decision-making in primary care often involves subconscious use of heuristics or mental 'rules of thumb' to generalise the typical symptoms of the diagnosed illness to the patient. Within the literature on decision-making, the psychological mechanism underlying this generalisation process is referred to as the 'representativeness heuristic'. Similarly, there are alternative heuristics that have been identified in clinical decisions and diagnostic judgments. ${ }^{9.11}$ While such heuristics are often employed subconsciously and have received praise for enabling 'fast and frugal' diagnoses, there is also evidence to indicate they can lead to judgmental bias in some instances. ${ }^{12-14}$ For example, clinicians who avoid making computer records during the consultation but do so afterwards, so called "minimal users," are more likely to include symptoms that fit with their diagnosis and exclude those that don't than doctors who record notes as they go. ${ }^{15}$ We also know that pay for performance targets for chronic disease management temporarily distort the recording of blood pressure. ${ }^{16}$ Hence, we suggest it is also possible that the clinicians in Barbara et al.'s study may have unknowingly documented additional symptoms as a result of a mental heuristic that would typically serve to facilitate efficient decision-making and maintain comprehensive medical records.

Defensive practice may also stimulate doctors to write more extensive records. Defensive medicine is well established in family practice, ${ }_{17}^{17}$ one of its characteristics is more detailed note-taking ${ }^{18}$ which is said to reduce the risk of malpractice suits. ${ }^{19} \mathrm{Although}$ family practitioners are in a relatively low-liability group they appear to have greater concerns about malpractice suits than higher risk specialities. ${ }^{20}$ These tensions may have been enhanced while participating in a clinical trial. It is plausible that physicians recorded more symptoms to justify not prescribing antibiotics; this is an interaction which merits exploration.

Our interpretation highlights the complex psychological interplay that can take place between patients and clinicians; reassuringly, this interaction may be underscored by a mutual desire to elicit or maintain a positive clinician-patient relationship, avoiding potential harm from a missed infection, and keeping detailed medical records.

There are two important implications of this study: ${ }^{1}$

- Firstly, policy makers should be mindful of the impact that public health decisions (e.g. cutting costs) can have upon a patient's perceived risk of not receiving an appropriate level of treatment. Such perceptions may cause patients to question the efficacy of the public health system and adopt counter-behaviours, "workarounds" to elicit their desired response.

- Secondly, clinicians must remain mindful of ensuring that the records they maintain are an accurate representation of the patient's actual health status. To this end, we recommend that clinicians should always ensure that a clear distinction is made in medical records between patient-reported symptoms and the symptoms observed by the clinician - as suggested in Weed's problem-orientated records. ${ }^{21}$ We must ensure that patients' medical records are sufficiently reliable to be used to inform important decisions.

Acknowledgements We would like to thank Dr Barbara for her prompt answers to questions raised by the authors. 
Conflicts of interest The authors declare that they have no conflicts of interest in relation to this article.

Commissioned article; not externally peer-reviewed; accepted 1st February 2012; online 23rd February 2012

(c) 2012 Primary Care Respiratory Society UK. All rights reserved http://dx.doi.org/10.4104/pcrj.2012.00024

Prim Care Respir J 2012:21(2):124-6

\section{References}

1. Barbara AM, Loeb M, Dolovich L, Brazil K, Russell M. Agreement between selfreport and medical records on signs and symptoms of respiratory illness. Prim Care Respir J 2012;21(2):145-52. http://dx.doi.org/10.4104/pcrj.2011.00098

2. Barry CA, Bradley $C P$, Britten N, Stevenson FA, Barber N. Patients' unvoiced agendas in general practice consultations: qualitative study. BMJ 2000;320(7244): 1246-50. http://dx.doi.org/10.1136/bmj.320.7244.1246

3. Hamm RM, Hicks RJ, Bemben DA. Antibiotics and respiratory infections: are patients more satisfied when expectations are met? J Fam Pract 1996;43(1):56-62.

4. Cosby JL, Francis N, Butler CC. The role of evidence in the decline of antibiotic use for common respiratory infections in primary care. The Lancet (Infectious Diseases) 2007;7(11):749-56. http://dx.doi.org/10.1016/\$1473-3099(07)70263-3

5. Marra F, Patrick DM, Chong M, Bowie WR. Antibiotic use among children in British Columbia, Canada. Journal of Antimicrobial Chemotherapy 2006;58(4):830-9. http://dx.doi.org/10.1093/jac/dkl275

6. Cockburn J, Pit S. Prescribing behaviour in clinical practice: patients' expectations and doctors' perceptions of patients' expectations-a questionnaire study. BMJ 1997;315(7107):520-3. http://dx.doi.org/10.1136/bmj.315.7107.520

7. Himmel W, Lippert-Urbanke E, Kochen MM. Are patients more satisfied when they receive a prescription? The effect of patient expectations in general practice. Scand J Prim Health Care 1997;15(3):118-22.

http://dx.doi.org/10.3109/ 02813439709018500

8. de Lusignan S, Wells SE, Hague NJ, Thiru K. Managers see the problems associated with coding clinical data as a technical issue whilst clinicians also see cultural barriers. Methods Inf Med 2003;42(4):416-22.

9. Elstein AS, Schwarz A. Clinical problem solving and diagnostic decision making: selective review of the cognitive literature. BMJ 2002;324(7339):729-32. http://dx.doi.org/10.1136/bmj.324.7339.729

10. Gigerenzer G, Gaissmaier W. Heuristic Decision Making. Annual Review of Psychology 2011;62(1):451-82. http://dx.doi.org/10.1146/annurev-psych-120709145346.

11. Kahneman D, Tversky A. Subjective probability: a judgment of representativeness. Cognitive Psychology 1972;3:430-54. http://dx.doi.org/10.1016/0010-0285(72)90016-3

12. Gigerenzer G, Todd PM, and the ABC Research Group. (1999). Simple Heuristics That Make Us Smart. Oxford: Oxford University Press.

13. Gigerenzer G. Goldstein DG. Reasoning the fast and frugal way: models of bounded rationality. Psychological Review 1996;103:650-69. http://dx.doi.org/10.1037/0033-295X.103.4.650

14. Gilovich T, Griffin D. Kahneman D. (eds.). (2002). Heuristics and Biases: The Psychology of Intuitive Judgment. Cambridge, UK.: Cambridge University Press.

15. Fitter MJ and Cruickshank PJ. The computer in the consulting room: a psychological framework. Behaviour and Information Technology 1983;1:81-92. http://dx.doi.org/10.1080/01449298208914438

16. Alsanjari ON, de Lusignan S, van Vlymen J, et al. Trends and transient change in end-digit preference in blood pressure recording: studies of sequential and longitudinal collected primary care data. Int J Clin Pract 2012;66(1):37-43. http://dx.doi.org/10.1111/j.1742-1241.2011.02781.x

17. Rosser WW. Threat of litigation. How does it affect family practice? Can Fam Physician 1994;40:645-8.

18. Summerton N. Positive and negative factors in defensive medicine: a questionnaire study of general practitioners. BMJ 1995;310(6971):27-9. http://dx.doi.org/10.1136/bmj.310.6971.27

19. Teichman PG. Documentation tips for reducing malpractice risk. Fam Pract Manag 2000;7(3):29-33

20. Bishop TF, Federman AD, Keyhani S. Physicians' views on defensive medicine: a national survey. Arch Intern Med 2010;170(12):1081-3. http://dx.doi.org/10.1001/archinternmed.2010.155

21. Weed LL. Medical records that guide and teach. N Eng/ J Med 1968;278(11):593600. http://dx.doi.org/10.1056/NEJM196803142781105

\section{Streptococcus pyogenes upper respiratory infections and their effect on atopic conditions}

\section{See linked article by Juhn et al. on pg 153}

\section{*Osman Mohammad Yusufa}

a The Allergy and Asthma Institute, Islamabad, Pakistan

*Correspondence: Dr Osman M Yusuf, The Allergy and Asthma Institute, 275 Gomal Road, Sector E-7, Islamabad, Pakistan 44000 Tel: (0092) 512654445 Fax: (0092) 512654446

E-mail: osman_allergy@yahoo.com

The effect of the upper airway on the lower airway was recognised as early as the second century by Claudius Galenus, who defined the nose as a 'respiratory instrument' in his work De usu partium (On the usefulness of the [body] parts). ${ }^{1}$ However, the modern concept of the upper and lower respiratory passages being a continuum and forming a single unified airway has been highlighted only over the last 10-15 years. ${ }^{2}$

The Allergic Rhinitis and its Impact on Asthma (ARIA) initiative focused on the co-morbidities of allergic rhinitis and included involvement of the eyes, the paranasal sinuses and the lower airways. ${ }^{3}$ The nasal and bronchial mucosa present a number of similarities, and one of the most important concepts regarding nose/lung interactions is their functional complementarity. ${ }^{4}$ Interactions between the upper and lower airways are well known; it has been observed that over $80 \%$ of asthma patients have rhinitis and $10-40 \%$ of patients with rhinitis have asthma. ${ }^{3}$

The role of upper respiratory tract infections (URTIS) and how they affect the lower respiratory tract have been less well studied compared to the role of allergic diseases. Similarly, the effects of URTIs on atopic conditions (other than asthma) have also not been documented to any appreciable extent. Asthma in children is associated with an increased risk of Streptococcus pyogenes upper respiratory infections, ${ }^{5}$ even though Strep. pyogenes is not known to be a cause of asthma exacerbations. ${ }^{6}$

Strep. pyogenes is a well-known causative agent of a number of autoimmune conditions. The relatively new disease PANDAS, supposedly of post-streptococcal etiology, is the acronym for Paediatric Autoimmune Neuropsychiatric Disease Associated with Streptococcal 